\title{
POSSIBILITIES TO APPLY CLASSICAL BANKRUPTCY PREDICTION MODELS IN THE CONSTRUCTION SECTOR IN LITHUANIA
}

\author{
Rasa Kanapickiene ${ }^{1}$, Rosvydas Marcinkevicius ${ }^{2}$ \\ ${ }^{1,2}$ Vilnius University, Lithuania \\ cross'ef http://dx.doi.org/10.5755/j01.em.19.4.8095
}

\begin{abstract}
The paper presents the results of a research of the application of bankruptcy prediction models in the construction sector in Lithuania. During the financial crisis, many companies in the construction sector went bankrupt. Therefore, the research aims to find out whether conventional bankruptcy prediction models are applicable in this sector. Moreover, Lithuanian researchers have contradictory opinions about the possibilities to apply bankruptcy prediction models. Empirical research studies provide conflicting results as well. It should also be noted that earlier Lithuanian research studies (1999-2013) featured a small sample of companies, which could have had an impact on great errors of the research results. The above mentioned reasons encourage evaluating the accuracy of bankruptcy prediction models by examining a large sample of companies and evaluating real benefits obtained from the acquired information.

The present study is distinguished by its large sample of companies that was compiled for the first time (433 companies in the construction sector that were filed for bankruptcy in 2009-2013 were examined). To achieve the aim of the research, i.e., to evaluate the applicability of bankruptcy prediction models in Lithuanian companies in the construction sector, 5 classical statistical bankruptcy prediction models were chosen: 3 linear discriminant analytical models (Altman, Springate, Taffler) and 2 logistic regression models (Chesser, Zavgren). From the Altman's models, the Altman's model for companies whose shares are not quoted in the stock exchange markets, Altman's Z"-Score Model for the service companies and Altman's Z"'-Score Model for emerging countries were investigated. From Taffler models, Taffler (1973) and Taffler \& Tisshaw (1977) models were analysed. Having carried out the research, it is possible to come to the conclusion that the most accurate bankruptcy prediction models with the highest bankruptcy probability are the following: the logistic regression adapted Chesser and Zavgren models; the accuracy of the linear discriminant Springate models is also high. The research proved that the Taffler and Altman's Z', Score Model for emerging countries models are least accurate.

The results of the research might be useful for both the executive managers of companies in the construction sector and investors who analyse the problems of the operation continuity.

The type of the article: Research paper.

Keywords: bankruptcy, bankruptcy prediction, bankruptcy prediction models.

JEL Classification: G33.
\end{abstract}

\section{Introduction}

Lithuanian economy underwent essential changes during the period of independence: it had to orient to a new economic market system, enter new markets, change the structure of economy and survive economic crises. Due to such quickly changing business conditions and more frequent financial crises, companies often face the problem of insolvency.

From 1993 till the end of 2013, there were 14535 bankrupts of companies and 16 bankrupts of banks. The growth of bankrupts was indicated during the crisis, namely, 957 companies were filed for bankruptcy in 2008, whereas the number reached 1844 companies in 2009. From 2010 till 2011, 
the number of bankrupts declined: 1637 business failures in 2010; 1273 bankrupts in 2011. In 2012, the number of initiated bankruptcy processes increased to 1401, whereas it reached 1551 companies in 2013 (Statistics Lithuania, 2014). High rate of bankruptcy indicates that companies are not able to rationally evaluate their financial situation. Therefore, to ensure business continuity and avoid bankrupts and their resulting consequences it is necessary to determine, evaluate and solve financial problems before the insolvency of companies becomes evident.

In order to identify the reasons of deterioration of a company's financial state and factors which determine the financial decline of the company as early as possible, the executives must constantly carry out bankruptcy prediction. The evaluation of a company's financial risk by applying bankruptcy prediction models might help the company to avoid going bankrupt. There are many models to predict bankruptcy and, according to Bivainis and Garškaite (2000), a company must choose the most appropriate and accurate bankruptcy prediction models. However, one might get lost in the variety of the proposed bankruptcy prediction models, especially due to the fact that not all models are suitable for bankruptcy prediction in Lithuania. Moreover, financial position of a company, continuity and prospects of its performance are evaluated not only by the company itself but also by other business entities: share-holders, investors, suppliers, etc. who, in their turn, use models of bankruptcy prediction as well.

Many scholars have investigated the problems of bankruptcy. A number of theoretical research studies were carried out, yet the majority of them focused on a single aspect only: they analysed bankruptcy signs, factors, reasons; created particular bankruptcy prediction models; analysed advantages and drawbacks of the created bankruptcy models. Complex means of bankruptcy threat prediction were also offered (Bivainis \& Garškaite, 2000), an integrated methodology of companies' bankruptcy prediction was created (Mackevičius, 2010).

Many scholars who have investigated various models of bankruptcy prediction have not come up to an agreement as to the suitability of bankruptcy prediction models to Lithuanian companies. Nonetheless, they emphasized the fact that the academic research in the field must be continued. The sample of companies in the majority of the empirical research studies of the suitability of bankruptcy models in Lithuania is not large. The research on the specifics of the application of bankruptcy models in different sectors of economic activity is also insufficient. The object of the research is bankruptcy prediction of companies. The aim of the research is to investigate and evaluate the possibilities to apply bankruptcy prediction models in Lithuanian companies in the construction sector. The formulation of the aim is drawn on the fact that mainly construction companies have gone bankrupt since the world crisis till now.

The paper is structured as follows: Part One presents and analyses the research of the application of bankruptcy prediction models in Lithuania; Part Two defines the research methodology applied in the present paper; Part Three presents and analyses the results of the research; Part Four provides discussion of the paper.

\section{The Research of the Application of Bankruptcy Prediction Models in Lithuania}

Lithuanian scholars have analysed both traditional multi-criteria and modern bankruptcy prediction models in their empirical studies (Table 1). Lithuanian researchers have mostly used the Altman model for examination and application of traditional bankruptcy prediction models. However, they have not reached a common agreement as to the application of this model in Lithuanian companies. Mackevičius and Poškaite (1999) employ the methodology of the analysis of the changes of financial statements in several years and use the Altman model to examine the bankruptcy probability of several companies whose shares are quoted in stock exchange markets. The researchers come to the conclusion about the expediency of the Altman model. Having investigated 30 cases of bankruptcy, Mackevičius and Rakštelienè (2005) suggest applying all three Altman's models to predict bankruptcy in Lithuanian companies. According to them, prediction must be carried out every year because the results of a single year do not lead to a univocal conclusion. However 
Tvaronavičienè (2001) adheres to even a stricter view by maintaining that this model is not appropriate to evaluate the insolvency of Lithuanian companies. After the analysis of the research studies, Mackevičius (2010) pointed out that the opinions of Lithuanian scholars regarding the Altman model differ because the tested companies come from different branches of industry and their number varies. Nevertheless, the conclusions of the scholars about the appropriateness of the model were reached by testing a small number of companies and it might have an impact on the reliability of the results. Further investigations embrace not only the Altman model but other traditional multi-criteria models of bankruptcy prediction. These investigations will be discussed in greater detail.

Grigaliūnienè and Cibulskiene (2004) employ three Altman models as well as Taffler \& Tisshaw, Springate, Fulmer and Ca-Score for a company's bankruptcy prediction. The scope of the investigation is restricted to the analysis of a single unprofitable services company. The authors determine that the bankruptcy of the company is ambiguous. They come to the conclusion that in Lithuania it is recommended to employ other traditional multi-criteria bankruptcy models beside the widely applicable Altman's model in order to achieve a more exhaustive analysis of bankruptcy probability. Purvinis, Šukys and Virbickaitè (2005) applied Altman, Taffler \& Tisshaw, Springate models in 13 companies and came to the conclusion that different models provide different bankruptcy probabilities.

Mackevičius and Silvanavičiūte (2006) examined the application of five classical statistical models: Altman (dedicated to evaluate companies whose shares are quoted in stock exchange), Taffler \& Tisshaw, Springate, Zavgren and Chesser. The scholars designated that 1) the most accurate bankruptcy probability was obtained by the models of linear discriminant analysis: Altman, Springate, Taffler \& Tisshaw; 2) the results of logistic regression models - Zavgren and Chesser - were contradictory, they often varied from those of linear analysis models and real financial state of the companies. The authors made a conclusion that linear discriminant analysis models Atman, Springate, Taffler \& Tisshaw are more appropriate to predict bankruptcy of Lithuanian companies than Zavgren and Chesser logistic regression models. The scholars also proposed to compare the results obtained by the bankruptcy prediction models with the short-term and long-term solvency and profitability indices. However, the relation between the solvency, profitability and bankruptcy of a company and the results obtained by bankruptcy prediction models have never been examined empirically.

Garškaite (2008) applied the Altman, Taffler \& Tisshaw, Springate and Liss models in Lithuanian companies from a single economic branch and came to the conclusion that the results of the models nearly match the real situation, i.e., they predict bankruptcy. The author found out that Taffler \& Tisshaw model corresponds to the real situation most accurately.

However, the scholar is not as strict regarding the appropriateness of the models; she states that it is not advisable to rely blindly on each of the models and their suitability to predict bankruptcy in Lithuanian companies because the peculiarities of both the state economy and activity of the company must be taken into consideration.

Similar results were obtained by Kiyak and Labanauskaite (2012), Jurevičienè and Bercevič (2013). Kiyak and Labanauskaite (2012) determined that the results of Altman and Springate models reflect the company's financial position; therefore, these models can be used for Lithuanian business bankruptcy prediction. Meanwhile, logistic analysis models (Chesser and Zavgren) contradict the results of linear discriminant analysis group model (Altman, Springate) and do not reflect the financial position, so their application can be only partial or unreliable to predict bankruptcy probability in Lithuanian companies. The limiting factor of Kiyak and Labanauskaitè's (2012) research is that the data of only one financial year was analysed. Jurevičienè and Bercevič (2013) applied the Altman, Springate, Taffler \& Tisshaw, Liss, Zavgren, Chesser models in Lithuanian transport companies. Despite the narrow sample of the research, which embraced 10 companies only, the research is important since it considers the data of three years before the bankruptcy of the companies. The authors found out that the application of these models in Lithuanian companies shows that, by using Altman model, it is possible to predict possible failure even three years before bankruptcy, yet with medium accuracy. Springate and 
Taffler \& Tisshaw models are also appropriate for the companies in this sector, however these models could help to predict possible failure only two years (Springate) or one year (Taffler \& Tisshaw) before bankruptcy, while Liss, Zavgren and Chesser models are unreliable for carrier enterprises due to ratios used for bankruptcy prediction.

The scientific insight that it is expedient to compare the results obtained by bankruptcy models with the indices of solvency and profitability was empirically checked by Budrikiené and Paliulytė (2012), Karalevičienè and Bužinskienè (2012a). The appropriateness of a bankruptcy model is determined by juxtaposing the results obtained by the model with the results of solvency and profitability relation matrix (Karalevičienè \& Bužinskienè, 2012a). The bankruptcy model is appropriate to predict bankruptcy of a company if it 1) shows bankruptcy probability for companies which, according to the solvency and profitability matrix, are a) insolvent-profitable companies; b) solvent-unprofitable companies; c) insolvent-unprofitable companies and 2) does not show bankruptcy probability for solvent-profitable companies.

Budrikienè and Paliulyte (2012) investigated the following six bankruptcy prediction models: Altman, Taffler \& Tisshaw, Springate, Lis, Zavgren, Chesser. The scholars revealed that Altman and Taffler \& Tisshaw models are appropriate to predict bankruptcy of companies: they showed low bankruptcy probability for the tested solvent-profitable companies, but for companies in other groups it foresaw high or possible bankruptcy probability. The authors denote that other models are appropriate to predict bankruptcy only for separate solvency-profitability groups of companies: 1) Lis model is inappropriate to predict bankruptcy of solvent-profitable companies; 2) Springate model is appropriate to predict bankruptcy of solvent-unprofitable and insolvent-unprofitable companies; 3) Zavgren model is appropriate for insolvent-profitable, solvent-unprofitable companies; 4) Chesser model is appropriate to predict bankruptcy of solvent-unprofitable companies only. It is suggested to judge the situation more conservatively: the four models should not be considered as models of high precision.

Karalevičienė and Bužinskienė (2012a) investigated modern models of bankruptcy prediction (Table 1). After the investigation of six companies, the scholars inferred that the analysed models, with the exception of Romania Bankruptcy and Shumway models, were suitable for the prediction of a company's bankruptcy. Yet, the academic approach ought to be more precise: some models, such as those offered by Grigaravičius and Stoškus et al. (these models did not predict bankruptcy for an insolvent and unprofitable company) or that of Seifulin and Kadykov (this model did not indicate bankruptcy for a solvent and unprofitable company) should not be included into the category of high precision models.

Kanapickienė, Rudžionienė and Griauslytė (2008) analysed bankruptcy prediction models from another angle: the companies were grouped not according to their solvency-profitability but according to their size. Kanapickiene et al. (2008) investigated the suitability of six bankruptcy prediction models in Lithuanian companies of various size. The list of models includes: Altman, Taffler \& Tisshaw, Springate, Zavgren, Grigavičius, Stundžienė \& Boguslauskas. It was determined that the analysed models do not always precisely indicate the probability of bankruptcy. The most appropriate ones to predict bankruptcy appeared to be that of Stundžienè \& Boguslauskas (in the group of small companies) and Altman (in the group of large companies).

To generalize the empirical research carried out, it is possible to state that scholars have no common agreement on the application of bankruptcy prediction models in Lithuania. For instance, Mackevičius and Silvanavičiūtė (2006) expressed doubts concerning complete reliance on each bankruptcy prediction model and its appropriateness to predict bankruptcy of Lithuanian companies because 1) the investigated bankruptcy prediction models were created at different times and countries which differ in the level of economic development and conditions of competition; 2) to create the models, financial data of companies operating in different fields of economic activity was used. Purvinis et al. (2005) are even more categorical: they claim that, due to the different conditions of operation between the companies which served as the basis for the created models and Lithuanian companies, the appropriateness of the models for bankruptcy prediction in Lithuania remains doubtful. 
Table 1. Empirical research of the appropriateness of bankruptcy prediction models in Lithuania

\begin{tabular}{|c|c|c|c|c|c|c|c|c|c|c|c|c|}
\hline \multirow{2}{*}{$\begin{array}{r}\begin{array}{r}\text { Investigated } \\
\text { bankruptcy } \\
\text { models* }\end{array} \\
\text { Empirical } \\
\text { research }\end{array}$} & \multicolumn{11}{|c|}{ Traditional multi-criteria bankruptcy models } & \multirow[b]{2}{*}{$\begin{array}{c}\text { Modern } \\
\text { bankruptcy } \\
\text { models }\end{array}$} \\
\hline & 傿 & 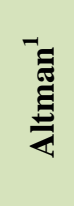 & 跑 & 苞 & 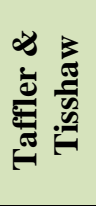 & 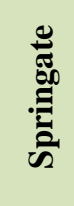 & $\stackrel{\mathscr{2}}{\beth}$ & 离 & 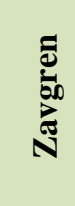 & 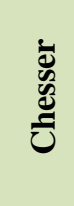 & 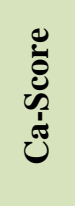 & \\
\hline $\begin{array}{l}\text { Mackevičius and } \\
\text { Poškaitė (1999) }\end{array}$ & & $\sqrt{ }$ & & & & & & & & & & \\
\hline $\begin{array}{l}\text { Tvaronavičienè } \\
\text { (2001) }\end{array}$ & & $\sqrt{ }$ & & & & & & & & & & \\
\hline $\begin{array}{l}\text { Grigaliūnienè } \\
\text { and Cibulskienè } \\
(2004)\end{array}$ & $\sqrt{ }$ & & $\sqrt{ }$ & $\sqrt{ }$ & $\sqrt{ }$ & $\sqrt{ }$ & & $\sqrt{ }$ & & & $\sqrt{ }$ & \\
\hline $\begin{array}{l}\text { Mackevičius and } \\
\text { Rakštelienė } \\
\text { (2005) }\end{array}$ & & $\sqrt{ }$ & $\sqrt{ }$ & $\sqrt{ }$ & & & & & & & & \\
\hline $\begin{array}{l}\text { Purvinis et al. } \\
\text { (2005) }\end{array}$ & & $\sqrt{ }$ & & & $\sqrt{ }$ & $\sqrt{ }$ & & & & & & \\
\hline $\begin{array}{l}\text { Mackevičius and } \\
\text { Silvanavičiūtė } \\
\text { (2006) }\end{array}$ & & $\sqrt{ }$ & & & $\sqrt{ }$ & $\sqrt{ }$ & & & $\sqrt{ }$ & $\sqrt{ }$ & & \\
\hline Garškaitė (2008) & $\sqrt{ }$ & $\sqrt{ }$ & $\sqrt{ }$ & & $\sqrt{ }$ & $\sqrt{ }$ & $\sqrt{ }$ & & & & & \\
\hline $\begin{array}{l}\text { Kanapickienè et } \\
\text { al. (2008) }\end{array}$ & & $\sqrt{ }$ & & & $\sqrt{ }$ & $\sqrt{ }$ & & & $\sqrt{ }$ & $\sqrt{ }$ & & $\sqrt{1}$ \\
\hline $\begin{array}{l}\text { Karalevičienė, } \\
\text { Bužinskienė } \\
\text { (2012a) }\end{array}$ & & & & & & & & & & & & $\sqrt{2}$ \\
\hline $\begin{array}{l}\text { Budrikiené and } \\
\text { Paliulyte (2012) }\end{array}$ & & $\sqrt{ }$ & & & $\sqrt{ }$ & $\sqrt{ }$ & $\sqrt{ }$ & & $\sqrt{ }$ & $\sqrt{ }$ & & \\
\hline $\begin{array}{l}\text { Kiyak, } \\
\text { Labanauskaitė } \\
\text { (2012) }\end{array}$ & & & $\sqrt{ }$ & & & $\sqrt{ }$ & & & $\sqrt{ }$ & $\sqrt{ }$ & & \\
\hline $\begin{array}{l}\text { Jurevičienė, } \\
\text { Bercevič (2013) }\end{array}$ & & & $\sqrt{ }$ & & $\sqrt{ }$ & $\sqrt{ }$ & $\sqrt{ }$ & & $\sqrt{ }$ & $\sqrt{ }$ & & \\
\hline Total & 2 & 8 & 5 & 2 & 7 & 8 & 3 & 1 & 5 & 5 & 1 & \\
\hline
\end{tabular}

*The classification of models according to Karalevičienė, Bužinskienè (2012b)

Altman ${ }^{0}$ - Altman's model of two indicators

Altman ${ }^{1}$ - Altman's Z-Score model dedicated for companies whose shares are quoted in a stock-exchange market

Altman $^{2}$ - Altman's Z'-Score model dedicated for companies whose shares are not quoted in a stock-exchange market

Altman ${ }^{3}$ - Altman's Z'-Score model dedicated for service and individual companies

${ }^{1}$ Grigavičius (2003); Stundžienė and Boguslauskas (2006) models

${ }^{2}$ Seifulin and Kadykov (1992), Begley, Ming and Watts (1996), Shumway (1999), model of predicting bankruptcy of Romania (1999-2002), Grigaravičius(2003); Inka and Neumaier (2005), Boritz et al. (2007), Sandin \& Porporato (2007), Stoškus et al. (2007), Bonity index (2009) models.

Moreover, Mackevičius (2010) points out that complete reliance on any bankruptcy prediction model should be avoided since the models join only several financial ratios.

Kiyak and Labanauskaite (2012) denote that one cannot rely on a single model and it is expedient to compare the results of several models while making decisions. Garškaite (2008) proposes to increase objectivity and reliability of bankruptcy prediction by creating a complex model embracing the most significant factors of the discussed models and adapting it to Lithuanian companies. Besides, scholars (Mackevičius \& Silvanavičiūtè, 2006; Garškaitè, 2008; Mackevičius, 2010) agree that the research of the application of bankruptcy models in Lithuania must proceed. It is worth mentioning that earlier research studies tackled small numbers of companies which could have determined a rather great inaccuracy of the results. The above mentioned reasons encourage evaluating the accuracy of bankruptcy prediction models by considering large numbers of companies as well as attesting real benefits of the acquired information. 


\section{Research methodology}

This chapter provides the research methodology of the applicability of the bankruptcy prediction models in the construction sector.

Data collection. While organizing the research, first of all, the population, sampling, minimal screening scope and the method of source data acquisition were determined.

Population. After the evaluation of the tendencies of bankruptcy development in Lithuania and with regard to the statistics of the business failures, companies forms the construction sector were selected for the present research. The choice was determined by the following factors:

1. According to the data of the Statistics Lithuania, there were 84574 economic operators in Lithuania on 1 January 2009, whereas on 1 January 2013, the number was 86929. The majority of the economic operators was constituted by business units working in the fields of manufacturing, construction, wholesale \& retail trade, and transport \& storage (on 1 January 2009, respective to the type of the economic activity $8.7 \% ; 8.4 \% ; 26.3 \% ; 7.2 \%$; on 1 January $2013,7.8 \% ; 6.9 \%$; $25 \%$; $7.5 \%)$.

2. What concerns these four major sectors, in 2009-2013, most of bankruptcy processes were initiated in the construction, wholesale \& retail trade, transport \& storage sectors (in 2009, respective to the type of the economic activity $23.6 \% ; 23.2 \% ; 14.9 \%$ ).

3 . The analysis of the sectors which show the highest bankruptcy rate reveals the fact that the construction sector had the highest per cent of the initiated bankruptcy processes in the respective year regarding the whole number of economic operators in the sector registered in the beginning of the year (6.1\% in 2009). Analogical tendency was observed till 2013. The latter reason is one of the main factors that determined the choice of the sector for the present research.

The population size. The present research is concerned with the construction companies filed for bankruptcy in 2009-2013. That is, 1571 bankruptcy processes were initiated in the construction sector during this period.

Sampling. In statistic investigation, the relevant data is obtained by means of sampling. Sampling is defined as a part of the population selected for the research which can properly and sufficiently represent the population and provide necessary information. The elements of the population for the research were selected by means of probability sampling.

Screening scope. The results of the sampling are always more or less inaccurate. This inaccuracy decreases, whereas the precision of the conclusions increases when the screening scope is extended. In order to evaluate the accuracy of bankruptcy prediction models and ensure the quality of the acquired data, empirical calculation of 521 companies filed for bankruptcy in 20092013 was carried out.

Source data acquisition. Annual financial statements of 2007-2012 of the investigated companies were analysed. 1985 sets of financial statements were acquired for the analysis. Additional requirements were held for the financial statements of these companies because different number of financial statement sets was acquired from different companies. Companies that met the following requirements were selected for further analysis: 1) they provided financial statements for the period of one year before being filed for bankruptcy; 2) they had complete sequence of financial statements. This requirement will be explained in greater detail. Suppose a company was filed for bankruptcy in $k$ year. Financial statements for the years $k-1, k-2, \ldots k-m$ are taken. If some financial statements since $k-1$ to $k-m$ are missing, such company is not analysed. Possibly, a company provided financial statements not only for $k-1$ but also for the year of being filed for bankruptcy or a year after it. The longest sequence included $k+3$ to $k-5$ years. In such a way 433 companies filed for bankruptcy in 2009-2013 were selected. 1574 sets of financial statements were analysed.

The following results were acquired: $95 \%$ probability and $4.01 \%$ error.

Research composition. To achieve the aim of the research, i.e., to evaluate the applicability of bankruptcy prediction models in Lithuanian companies of the construction sector, classical statistical bankruptcy prediction models were chosen: linear discriminant analytical models (Altman, Springate, Taffler) (Table 2) and logistic regression models (Chesser, Zavgren) (Table 
3).These are the models that were mainly analysed in the empirical research studies of Lithuanian scholars. Some peculiarities of the investigated models will be discussed.

In the present paper, several versions of the Altman's model are investigated. The Altman's model (1968) that is dedicated to companies whose shares are quoted in a stock exchange market was not tested in the present research since the majority of the sampled companies are private limited companies, i.e. their shares are not traded on a stock exchange market. Hence, the model dedicated to companies whose shares are not quoted on a stock exchange market (the Z'-Score model) is tested. As the research analyses construction companies, i.e. such companies that may provide other services besides construction (such as architecture services, engineering services and relevant technical consultations, services of technical screening and analysis), the model Z"-Score is tested, i.e. a model dedicated to service companies. Altman, Danovi and Falini (2013) denote that the Z"-Score (Altman, Hartzell \& Peck, 1995) was introduced for the service as well as manufacturing sectors or companies operating in developing countries (the 1995 study investigated a sample of Mexican companies). The variables of the Z'-Score were the same as the Z'-Score model with the exclusion of the sales/total assets (see Table 2). In calculating the Z"-Score for emerging countries, Altman, Hartzell and Peck (1995) proposed adding a constant $(+3.25)$. This version of the model has not been applied for Lithuanian companies so far.

Table 2. Linear discriminant analytical models of bankruptcy prediction

\begin{tabular}{|c|c|c|}
\hline Author & Model & Elements of the model \\
\hline $\begin{array}{l}\text { Altman Z'-Score } \\
\text { model for companies } \\
\text { whose shares are not } \\
\text { quoted in stock } \\
\text { exchange markets } \\
\text { (was developed in } \\
\text { 1983) }\end{array}$ & $\begin{array}{l}\text { Z'=0.717X1+0.847X2 + 3.107X3 }+ \\
0.42 X 4+0.998 X 5 \\
\text { Z'> } 2.90 \text { - "Safe" Zone } \\
1.23<Z \text { ' }<2.90 \text { - "Grey" Zone } \\
\text { Z' }<1.23 \text { - "Distress" Zone }\end{array}$ & $\begin{array}{l}\text { X1 }=\text { Working Capital } / \text { Total Assets } \\
\text { X2 }=\text { Retained Earnings } / \text { Total Assets } \\
\text { X3 }=\text { EBIT } / \text { Total Assets } \\
\text { X4 }=\text { Book Value of Equity } / \text { Total Liabilities } \\
\text { X5 }=\text { Sales } / \text { Total Assets }\end{array}$ \\
\hline $\begin{array}{l}\text { Altman Z"-Score } \\
\text { Model for the service } \\
\text { companies (was } \\
\text { developed in 1995) }\end{array}$ & $\begin{array}{l}Z "=6.56 \mathrm{X} 1+3.26 \mathrm{X} 2+6.72 \mathrm{X} 3+ \\
1.05 \mathrm{X} 4 \\
\mathrm{Z} ">2.60 \text { - "Safe" Zone } \\
1.1<\mathrm{Z} \text { " }<2.60 \text { - "Grey" Zone } \\
\mathrm{Z} "<1.1 \text { - "Distress" Zone }\end{array}$ & $\begin{array}{l}\text { X1 }=\text { Working Capital } / \text { Total Assets } \\
\text { X2 }=\text { Retained Earnings } / \text { Total Assets } \\
\text { X3 }=\text { EBIT } / \text { Total Assets } \\
\text { X4 }=\text { Book Value of Equity } / \text { Total Liabilities }\end{array}$ \\
\hline $\begin{array}{lr}\text { Altman } & \text { Z"-Score } \\
\text { Model for } & \text { emerging } \\
\text { countries } & \text { (was } \\
\text { developed in 1995) } & { }^{1}\end{array}$ & $\begin{array}{l}Z "=3.25+6.56 \mathrm{X} 1+3.26 \mathrm{X} 2+ \\
6.72 \mathrm{X} 3+1.05 \mathrm{X} 4 \\
\mathrm{Z} ">2.60-\text { "Safe" Zone } \\
1.1<\mathrm{Z} \text { " }<2.60 \text { - "Grey" Zone } \\
\mathrm{Z} "<1.1 \text { - "Distress" Zone }\end{array}$ & $\begin{array}{l}\text { X1 = Working Capital / Total Assets } \\
\text { X2 = Retained Earnings / Total Assets } \\
\text { X3 = Earnings Before Interest and Taxes / Total } \\
\text { Assets } \\
\text { X4 = Book Value of Equity / Total Liabilities }\end{array}$ \\
\hline $\begin{array}{l}\text { Springate model } \\
\text { (was developed in } \\
1978)^{2}\end{array}$ & $\begin{array}{l}Z=1.03 X 1+3.07 X 2+0.66 \times 3+0.4 \\
X 4 \\
\text { Failed } Z<0.862\end{array}$ & $\begin{array}{l}\text { X1 }=\text { Working Capital } / \text { Total Assets } \\
\text { X2 }=\text { EBIT } / \text { Total Assets } \\
\text { X3 }=\text { EBIT } / \text { Current Liabilities } \\
\text { X4 }=\text { Sales } / \text { Total Assets }\end{array}$ \\
\hline Taffler models & $\begin{array}{l}Z=0,53 X 1+0,13 X 2+0,18 X 3+ \\
0,16 \times 4\end{array}$ & $\begin{array}{l}\text { X1 }=\text { Profit before tax/current liabilities } \\
\text { X2 }=\text { Current assets/total liabilities } \\
\text { X3 }=\text { Current liabilities/total assets }\end{array}$ \\
\hline $\begin{array}{l}\text { Taffler \& Tisshaw } \\
\text { model } \quad \text { (was } \\
\text { developed in 1977) }\end{array}$ & $\begin{array}{l}\text { If value } \mathrm{Z} \text { exceeds } 0.3 \text {, long-term } \\
\text { prospects of a company are positive, if } \\
\text { value } \mathrm{Z} \text { is less than } 0.2 \text {, there is a } \\
\text { bankruptcy threat. }\end{array}$ & $\begin{array}{l}\text { X4= No-credit interval; } \\
\text { No-credit interval }=(\text { Immediate Assets - Current } \\
\text { Liabilities }) /(\text { Operating Costs }- \text { Depreciation })\end{array}$ \\
\hline $\begin{array}{l}\text { Taffler model (was } \\
\text { developed in 1973) }\end{array}$ & $\begin{array}{l}\text { If value } \mathrm{Z} \text { exceeds } 0.3 \text {, long-term } \\
\text { prospects of a company are positive, if } \\
\text { value } \mathrm{Z} \text { is less than } 0.2 \text {, there is a } \\
\text { bankruptcy threat. }\end{array}$ & X4=Revenue/ Total Assets \\
\hline
\end{tabular}

Source: ${ }^{1}$ Altman, Danovi and Falini (2013), ${ }^{2}$ Kasilingam and Ramasundaram (2012), Boritz, Kennedy \& Sun (2007), ${ }^{3}$ Harris (2010); ${ }^{4}$ Shemetev (2012); 
Springate's classification rule is that companies are classified as failed if $Z<0.862$ (Boritz et $a l ., 2007)$, therefore, the companies will only be divided into two groups: the companies that are at risk of bankruptcy (Distress Zone) and the companies that are at risk of bankruptcy (Safe Zone).

Taffler has created several versions of the model which vary by member X4. In Taffler \& Tisshaw (1977) model, X4 is no-credit interval. More directly, it is defined as (Immediate assets-Current liabilities)/operating costs excluding depreciation (Harris, 2010). In the Taffler model created in 1973, X4 = Revenue/Total Assets. Therefore, both variants of the models are analysed in the present paper.

Research restrictions: 1) X4 of Taffler \& Tisshaw (1977) model - no-credit interval - is calculated without respect to the depreciation because depreciation has no separate line in financial statements of companies; 2) profit (loss) statements used in Lithuania do not provide EBIT (Earnings before interest and taxes). Therefore, EBIT is substituted by EBT (Earnings before taxes) in models using EBIT.

In logistic regression models the bankruptcy probability is calculated by the following formula: $\mathrm{P}(\mathrm{Z})=1 /\left(1+\mathrm{e}^{-\mathrm{Z}}\right)$, where $\mathrm{P}$ is bankruptcy probability (from 0 to 1 ), and $\mathrm{Z}$ is $\mathrm{Z}$ value of the analyzed model (Table 3 ). When $P>50 \%$, there is a bankruptcy probability; when $P \leq 50 \%$, there isn't any bankruptcy threat to a company. When assessing the probability of bankruptcy, the "Grey Zone" is not distinguished in logistic regression models, whereas it is frequently distinguished in linear discriminant analytical models.

The Zavgren model is distinguished for using different coefficients for bankruptcy prediction, depending on how old the analysed data of the financial statements is: the model predicts bankruptcy from one to five years prior to bankruptcy initiation (i.e., $k-1, k-2, k-3, k-4, k-5$ years). When the model is presented in such a way, it is impossible to check whether the model is valid for failed companies. Therefore, bankruptcy probabilities of $k, k+1, k+2, k+3$ years (i.e., at the time of bankruptcy and after years of filing for bankruptcy bankruptcy) have not been calculated in the research.

Table 3. Logistic regression models of bankruptcy prediction

\begin{tabular}{|c|c|c|}
\hline Author & Model & Elements of the model \\
\hline $\begin{array}{l}\text { Zavgren model (was } \\
\text { developed in 1985) }\end{array}$ & 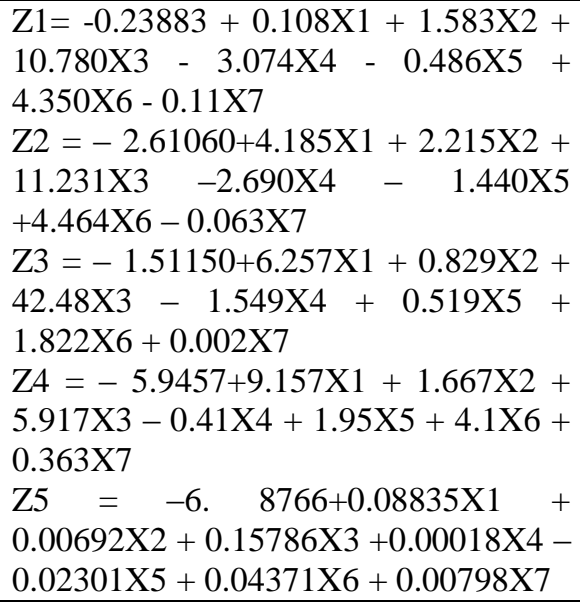 & $\begin{array}{l}\text { X1=Inventories/Net Sales } \\
\text { X2=Receivables/ Inventories } \\
\text { X3= Cash/ Total Assets } \\
\text { Z4= Quick Assets/Current Liabilities } \\
\text { X5= Sales/Net Plant where Net Plant = Total Assets } \\
\text { - Current Liabilities } \\
\text { X6= Debt/Total Capital } \\
\text { X7= Total Income/Total Capital }\end{array}$ \\
\hline $\begin{array}{l}\text { Chesser model } \\
\text { (was developed in } \\
1974)^{2}\end{array}$ & $\begin{array}{l}Z=-2.0434-5.24 X 1+0.0053 X 2- \\
6.6507 X 3+4.4009 X 4-0.0791 X 5- \\
0.1021 X 6\end{array}$ & $\begin{array}{l}\text { X1=Cash/Total Assets } \\
\text { X2=Net Sales/Cash } \\
\text { X3=EBIT /Total Assets } \\
\text { X4=Total Liabilities /Total Assets } \\
\text { X5=Long-Term Assets/ Equity } \\
\text { X6=Working Capital /Net Sales } \\
\text { (Mackevičius \& Silvanavičiūtė, 2006) }\end{array}$ \\
\hline
\end{tabular}

Source: ${ }^{1}$ Zavgren (1985); ${ }^{2}$ Mackevičius \& Silvanavičiūtė (2006) 


\section{Results}

To achieve the aim of the research, i.e., to evaluate the applicability of bankruptcy prediction models in Lithuanian companies, classical statistical bankruptcy prediction models were chosen: linear discriminant analytical models (Altman, Springate, Taffler) and logistic regression models (Chesser, Zavgren).

Altman's models. According to the research results (Table 4), it is possible to state that the prediction accuracy of the Z"-Score Model for emerging countries is the least sufficient one in comparison with other Altman models under investigation: Z"-Score Model for emerging countries shows accuracy by 20 points less than other Altman models in the period of one-three years before filing for bankruptcy.

By applying the Z'-Score model in the companies from the construction sector it was discovered that 332 companies out of 433 had a real bankruptcy threat one year before the bankruptcy initiation (Table 4). In order to determine the accuracy of the model, the accuracy of the bankruptcy prediction model was calculated. It comprised $76.7 \%$ with regard to the total number of the companies in the sector. The accuracy of bankruptcy prediction model decreases when the period considered is two years before the bankruptcy initiation. It was designated that 214 companies in the construction sector had a bankruptcy threat (the accuracy of the prediction model is only $51.4 \%$ ). If the period of three years before the bankruptcy initiation is taken into consideration, the accuracy of the prediction model declines even more. Regarding the construction sector, there were 130 companies whose critical value $\mathrm{Z}$ indicated a threat of bankruptcy, which comprised $43 \%$ of the accuracy of the prediction model.

Table 4. Calculation of bankruptcy probability by the Altman bankruptcy prediction models

\begin{tabular}{|c|c|c|c|c|c|c|c|c|c|}
\hline \multirow{2}{*}{ Year } & \multirow{2}{*}{$\begin{array}{l}\text { Number of } \\
\text { companies }\end{array}$} & \multicolumn{2}{|c|}{ Distress Zone } & \multicolumn{2}{|c|}{ Safe Zone } & \multicolumn{2}{|c|}{ Grey Zone } & \multicolumn{2}{|c|}{$\begin{array}{c}\text { Model is not } \\
\text { applied }\end{array}$} \\
\hline & & Firms & $\%$ & Firms & $\%$ & Firms & $\%$ & Firms & $\%$ \\
\hline \multicolumn{10}{|c|}{ Z'-Score Model for companies whose shares are not quoted in stock-exchange markets } \\
\hline $\begin{array}{l}\text { After filing for } \\
\text { bankruptcy } \\
(k+1, \quad k+2, \\
k+3)\end{array}$ & 44 & 44 & 100 & 0 & 0 & 0 & 0 & 0 & 0 \\
\hline $\mathrm{k}$ & 153 & 147 & 96.1 & 4 & 2.6 & 2 & 1.3 & 0 & 0 \\
\hline $\mathrm{k}-1$ & 433 & 332 & 76.7 & 37 & 8.5 & 63 & 14.5 & 1 & 0.3 \\
\hline $\mathrm{k}-2$ & 416 & 214 & 51.4 & 75 & 18.0 & 126 & 30.3 & 1 & 0.3 \\
\hline $\mathrm{k}-3$ & 302 & 130 & 43.0 & 94 & 31.1 & 75 & 24.8 & 3 & 1.1 \\
\hline $\mathrm{k}-4$ & 156 & 66 & 42.3 & 55 & 35.3 & 34 & 21.8 & 1 & 0.6 \\
\hline $\mathrm{k}-5$ & 65 & 19 & 29.2 & 26 & 40.0 & 19 & 29.2 & 1 & 1.6 \\
\hline \multicolumn{10}{|c|}{ Z'-Score Model for the service companies } \\
\hline $\mathrm{k}+1, \mathrm{k}+2, \mathrm{k}+3$ & 44 & 43 & 97.7 & 0 & 0 & 1 & 2.3 & 0 & 0 \\
\hline $\mathrm{k}$ & 153 & 138 & 90.2 & 9 & 5.9 & 6 & 3.9 & 0 & 0 \\
\hline $\mathrm{k}-1$ & 433 & 332 & 76.7 & 59 & 13.6 & 41 & 9.5 & 1 & 0.2 \\
\hline $\mathrm{k}-2$ & 416 & 235 & 56.5 & 127 & 30.5 & 53 & 12.7 & 1 & 0.3 \\
\hline $\mathrm{k}-3$ & 302 & 141 & 46.7 & 112 & 37.1 & 46 & 15.2 & 3 & 1.0 \\
\hline $\mathrm{k}-4$ & 156 & 68 & 43.6 & 66 & 42.3 & 21 & 13.5 & 1 & 0.6 \\
\hline $\mathrm{k}-5$ & 65 & 23 & 35.4 & 31 & 47.7 & 10 & 15.4 & 1 & 1.5 \\
\hline \multicolumn{10}{|c|}{ Z'-Score Model for emerging countries } \\
\hline $\mathrm{k}+1, \mathrm{k}+2, \mathrm{k}+3$ & 44 & 37 & 84.1 & 3 & 6.8 & 4 & 9.1 & 0 & 0 \\
\hline $\mathrm{k}$ & 153 & 125 & 81.7 & 20 & 13.1 & 8 & 5.2 & 0 & 0 \\
\hline $\mathrm{k}-1$ & 433 & 242 & 55.9 & 149 & 34.4 & 41 & 9.5 & 1 & 0.2 \\
\hline $\mathrm{k}-2$ & 416 & 123 & 29.6 & 256 & 61.5 & 36 & 8.7 & 1 & 0.2 \\
\hline $\mathrm{k}-3$ & 302 & 63 & 20.9 & 214 & 70.9 & 22 & 7.3 & 3 & 0.9 \\
\hline k-4 & 156 & 37 & 23.7 & 105 & 67.3 & 13 & 8.3 & 1 & 0.7 \\
\hline $\mathrm{k}-5$ & 65 & 10 & 15.4 & 47 & 72.3 & 7 & 10.8 & 1 & 1.5 \\
\hline
\end{tabular}

$k$ - the year of filing for bankruptcy

Source: created by the authors 
Z'-Score Model for the service companies is a little more accurate than Z'-Score (Table 4). However, having evaluated errors of the research it is possible to assume that the accuracy of these models is equal.

According to the scientific literature (Karalevičienè \& Bužinskienė, 2012b), when the Altman model is applied, the possibility to indicate bankruptcy probability is $95 \%$ one year before the bankruptcy initiation. It reaches $72 \%$ two years before the bankruptcy initiation. Nonetheless, the research has proved that the accuracy of the Altman model (in case of Z'-Score model) is much lower when it is applied in Lithuanian companies of the construction sector: it is lower by 18 percentage points when bankruptcy is being predicted one year before bankruptcy initiation and by 20.6 percentage points when bankruptcy is being predicted two years before bankruptcy initiation.

It is interesting to note that when the financial data of companies after filing for bankruptcy is analysed, Z'-Score Model shows bankruptcy for all companies (Z"'-Score Model for the service companies - $97.7 \%$ of companies). In the year of filing for bankruptcy, models show high bankruptcy probability (Z' Score Model - 96.1\%; Z"-Score Model for the service companies $90.2 \%)$. It is a pity, however, that this information cannot be used for bankruptcy prediction.

Investigated models use financial ratios to evaluate bankruptcy. There might be cases when a model cannot be applied because the denominator of the ratio fraction is equal to 0. For instance, the index $X 4=$ Book Value of Equity/ Total Liabilities, if Total Liabilities=0, then division from 0 is impossible, consequently, Z'-Score is not calculated. Such cases are very rare in the Altman models and have no impact on the accuracy of the models.

Springate model. One year before filing for bankruptcy, 384 companies in the construction sector had a bankruptcy threat (accuracy of the model is $88.7 \%$ ). When data of the two-year period before the bankruptcy initiation is being examined, the accuracy of the model is $67.1 \%$. The accuracy of the model decreases even more when the data is tested three years before the bankruptcy initiation (Table 5). According to the scientific literature (Kasilingam \& Ramasundaram, 2012), the Springate model reached the accuracy of $88 \%$. However, in Lithuanian companies such accuracy is obtained only if the model is applied one year before bankruptcy initiation.

Interestingly, the analysis of financial data of the companies after filing for bankruptcy reveals that the model shows bankruptcy for all companies, just as in case of Altman Z'-Score Model. High accuracy of the model is detected in the year of filing for bankruptcy. The cases when the Springate model is not applicable due to the impossible division from 0 are rare, as it is with Altman models. Thus, supposedly they have no impact on the accuracy of the models.

Table 5. Calculation of bankruptcy probability by the Springate bankruptcy prediction model

\begin{tabular}{|l|c|c|c|c|c|c|c|}
\hline \multirow{2}{*}{ Year } & \multirow{2}{*}{$\begin{array}{c}\text { Number of } \\
\text { companies }\end{array}$} & \multicolumn{2}{|c|}{ Distress Zone } & \multicolumn{2}{c|}{ Safe Zone } & \multicolumn{2}{c|}{$\begin{array}{c}\text { Model is not } \\
\text { applied }\end{array}$} \\
\cline { 3 - 8 } & & Firms & $\%$ & Firms & $\%$ & Firms & $\%$ \\
\hline $\mathrm{k}+1, \mathrm{k}+2, \mathrm{k}+3$ & 44 & 44 & 100 & 0 & 0 & 0 & 0 \\
\hline $\mathrm{k}$ & 153 & 148 & 96.7 & 4 & 2.6 & 1 & 0.7 \\
\hline $\mathrm{k}-1$ & 433 & 384 & 88.7 & 49 & 11.3 & 0 & 0 \\
\hline $\mathrm{k}-2$ & 416 & 279 & 67.1 & 137 & 32.9 & 0 & 0 \\
\hline $\mathrm{k}-3$ & 302 & 166 & 55.0 & 135 & 44.7 & 1 & 0.3 \\
\hline $\mathrm{k}-4$ & 156 & 84 & 53.8 & 72 & 46.2 & 0 & 0 \\
\hline $\mathrm{k}-5$ & 65 & 29 & 44.6 & 36 & 55.4 & 0 & 0 \\
\hline
\end{tabular}

Source: created by the authors

Taffler models. Bankruptcy was predicted by using two models: Taffler (1973) and Taffler \& Tisshaw (1977).

Calculations revealed that Taffler (1973) model is not accurate. It is possible to assume that the accuracy of the model is very low (Table 6). Among the construction sector companies, 155 had 
a bankruptcy threat one year before the bankruptcy initiation (the accuracy of the model is $35.8 \%$ ). When two years period before the bankruptcy initiation is considered, the bankruptcy prediction model shows the accuracy of $28.1 \%$. Three years before the bankruptcy initiation the accuracy of the bankruptcy prediction model is even lower. Scholars indicate that the accuracy of the Taffle \& Tisshaw model one year before the bankruptcy initiation is $97 \%$ (Mackevičius \& Silvanavičiūtè, 2006). Nevertheless the application of the model in Lithuanian companies shows the accuracy to be lower by 1.3 times. This model predicts bankruptcy for a very small number of companies, even though they have already been filed for bankruptcy (in the year of filing for bankruptcy - $37.3 \%$ of companies, after filing for bankruptcy - $20.5 \%$ of companies).

The accuracy of the Taffler \& Tisshaw (1977) model is much higher: it is similar to that of Altman models (Z'-Score Model and Z'-Score Model for the service companies): predicted bankruptcy probability one year before bankruptcy is only by 2.3 points worse than that predicted by the mentioned Altman models, while the accuracy of the prediction is higher by 9-11 points twofour years before (in comparison with the Z'-Score Model) and 5-8 points (in comparison with the Z"-Score Model for the service companies) respectively. Interestingly, the accuracy of the model does not increase when data of business failures is calculated: it remains about $75 \%$, i.e. the same as the accuracy of the model one year before filing for bankruptcy.

Table 6. Calculation of bankruptcy probability by applying the Taffler bankruptcy prediction models

\begin{tabular}{|c|c|c|c|c|c|c|c|c|c|}
\hline \multirow{2}{*}{ Year } & \multirow{2}{*}{$\begin{array}{l}\text { Number of } \\
\text { companies }\end{array}$} & \multicolumn{2}{|c|}{ Distress Zone } & \multicolumn{2}{|c|}{ Safe Zone } & \multicolumn{2}{|c|}{ Grey Zone } & \multicolumn{2}{|c|}{$\begin{array}{c}\text { Model is not } \\
\text { applied }\end{array}$} \\
\hline & & Firms & $\%$ & Firms & $\%$ & Firms & $\%$ & Firms & $\%$ \\
\hline \multicolumn{10}{|l|}{ Taffler (1973) } \\
\hline $\mathrm{k}+1, \mathrm{k}+2, \mathrm{k}+3$ & 44 & 9 & 20.5 & 27 & 61.4 & 7 & 15.9 & 1 & 2.2 \\
\hline $\mathrm{k}$ & 153 & 57 & 37.3 & 70 & 45.8 & 25 & 16.3 & 1 & 0.6 \\
\hline $\mathrm{k}-1$ & 433 & 155 & 35.8 & 221 & 51.0 & 54 & 12.5 & 3 & 0.7 \\
\hline $\mathrm{k}-2$ & 416 & 117 & 28.1 & 248 & 59.6 & 50 & 12.0 & 1 & 0.3 \\
\hline$k-3$ & 302 & 72 & 23.8 & 197 & 65.2 & 28 & 9.3 & 5 & 1.7 \\
\hline k-4 & 156 & 37 & 23.7 & 105 & 67.3 & 13 & 8.3 & 1 & 0.7 \\
\hline k-5 & 65 & 13 & 20.0 & 48 & 73.8 & 3 & 4.6 & 1 & 1.6 \\
\hline \multicolumn{10}{|c|}{ Taffler \& Tisshaw (1977) } \\
\hline $\mathrm{k}+1, \mathrm{k}+2, \mathrm{k}+3$ & 44 & 33 & 75.0 & 4 & 9.1 & 1 & 2.3 & 6 & 13.6 \\
\hline $\mathrm{k}$ & 153 & 116 & 75.8 & 32 & 20.9 & 2 & 1.3 & 3 & 2.0 \\
\hline k-1 & 433 & 322 & 74.4 & 75 & 17.3 & 23 & 5.3 & 13 & 3.0 \\
\hline $\mathrm{k}-2$ & 416 & 255 & 61.3 & 117 & 28.1 & 36 & 8.7 & 8 & 1.9 \\
\hline k-3 & 302 & 165 & 54.6 & 93 & 30.8 & 29 & 9.6 & 15 & 5.0 \\
\hline k-4 & 156 & 80 & 51.3 & 57 & 36.5 & 15 & 9.6 & 4 & 2.6 \\
\hline k-5 & 65 & 25 & 38.5 & 33 & 50.8 & 5 & 7.7 & 2 & 3.0 \\
\hline
\end{tabular}

Source: created by the authors

Chesser model. As Table 7 shows, a bankruptcy threat one year before the bankruptcy initiation was indicated in 315 companies from the construction sector (the accuracy of the model is $72.7 \%$ ). Considering the data of two and three years before the bankruptcy initiation in the companies of the construction sector, the accuracy of the model is $67.5 \%$ and $55.6 \%$ respectively.

According to scientific research studies, the accuracy of the Chesser bankruptcy prediction model is $78 \%$ one year before bankruptcy initiation, $57 \%$ two years before the bankruptcy initiation, therefore, the model was not acknowledged to be an accurate one (Karalevičienè \& Bužinskiene, 2012b). The research of the situation in Lithuania shows similar results.

However, it should be noted that the model could not be applied for a huge number of companies, i.e. $21 \%$ of companies (a year before filing for bankruptcy), $14 \%$ of companies (three, 
five years before filing for bankruptcy) (Table 7), because the denominator of the ratio fraction used in the model is equal to 0. Most often X2=Net Sales/Cash and X6=Working Capital /Net Sales indices cannot not be calculated.

Hence, the following situation was analysed: how the accuracy of the model would change if ratio indices that are impossible to calculate were equalled to 0 (Table 7). It was discovered that in such case model could not be applied only up to $1 \%$ of companies. One year before the bankruptcy initiation, the accuracy of the model increased by 19 points and reached $78.1 \%$. Two years before the initiation of bankruptcy, the accuracy of the model increased by 11 points and reached $91.5 \%$. Moreover, the accuracy of the model increased most in the year of filing for bankruptcy (by 27 points).

Table 7. Calculation of bankruptcy probability by the Chesser bankruptcy prediction model

\begin{tabular}{|l|c|c|c|c|c|c|c|}
\hline \multirow{2}{*}{ Year } & \multirow{2}{*}{$\begin{array}{c}\text { Number of } \\
\text { companies }\end{array}$} & \multicolumn{2}{|c|}{ Distress Zone } & \multicolumn{2}{c|}{ Safe Zone } & \multicolumn{2}{c|}{$\begin{array}{c}\text { Model is not } \\
\text { applied }\end{array}$} \\
\cline { 3 - 8 } & & Firms & $\%$ & Firms & $\%$ & Firms & $\%$ \\
\hline k+1, k+2, k+3 & 44 & 39 & 88.6 & 1 & 2.3 & 4 & 9.1 \\
\hline k & 153 & 100 & 65.4 & 8 & 5.2 & 45 & 29.4 \\
\hline k-1 & 433 & 315 & 72.7 & 28 & 6.5 & 90 & 20.8 \\
\hline k-2 & 416 & 281 & 67.5 & 80 & 19.2 & 55 & 13.3 \\
\hline k-3 & 302 & 168 & 55.6 & 92 & 30.5 & 42 & 13.9 \\
\hline k-4 & 156 & 79 & 50.6 & 59 & 37.8 & 18 & 11.6 \\
\hline k-5 & 65 & 30 & 46.2 & 26 & 40.0 & 9 & 13.8 \\
\hline Ratio indices that are impossible to calculate are equalled to $0:$ & & & \\
\hline k+1, k+2, k+3 & 44 & 43 & 97.7 & 1 & 2.3 & - & - \\
\hline k & 153 & 142 & 92.8 & 10 & 6.5 & 1 & 0.7 \\
\hline k-1 & 433 & 396 & 91.5 & 34 & 7.9 & 3 & 0.7 \\
\hline k-2 & 416 & 325 & 78.1 & 89 & 21.4 & 2 & 0.5 \\
\hline k-3 & 302 & 197 & 65.2 & 104 & 34.4 & 1 & 0.3 \\
\hline k-4 & 156 & 91 & 58.3 & 65 & 41.7 & - & - \\
\hline k-5 & 65 & 37 & 56.9 & 28 & 43.1 & - & - \\
\hline
\end{tabular}

Source: created by the authors

Zavgren model. As Table 8 shows, 324 companies in the construction sector were indicated as suffering a bankruptcy threat one year before the bankruptcy initiation (the accuracy of the model is $74.8 \%$ ). When the data of two and three years before the bankruptcy initiation is considered, the accuracy of the model in the construction sector is $79.3 \%$ and $83.8 \%$ respectively

The accuracy of the Zavgren model 1-2 years before the bankruptcy initiation is $82 \%$, whereas 3-4 years before the bankruptcy initiation it falls to $73 \%$ (Karalevičienè \& Bužinskiené, $2012 \mathrm{~b}$ ). The accuracy of the model in the investigated sample was lower by 3-7 points 1-2 years before filing for bankruptcy, while it was higher by 10-11 points 3-4 years before filing for bankruptcy. The attention should be brought to a rather paradoxical situation: in the construction sector, the model is more accurate when the data of 2-4 years before the bankruptcy initiation is considered in comparison with the examination of the data of one year before the bankruptcy initiation.

It is worth noting that the Zavgren model, just as the Chesser model, could not be applied to a large number of companies (Table 8 ) because the denominator of the ratio fraction used in the model is equal to 0 . Most often $X 1=$ Inventories/Net Sales, $X 2=$ Receivables/Inventories, $Z 4=$ Quick Assets/Current Liabilities indices cannot be calculated.

Hence, the following situation was analysed: how the accuracy of the model would change if ratio indices that are impossible to calculate were equalled to 0 (Table 8). It was revealed that in such case, model could be applied to practically all companies, but the accuracy of the model 
decreased significantly. One year before the bankruptcy initiation, the accuracy of the model decreased by 15 points; two years before the initiation of bankruptcy - by 38 points, three years by 36 points, four years - by 49 points.

Table 8. Calculation of bankruptcy probability by applying the Zavgren bankruptcy prediction model

\begin{tabular}{|l|c|c|c|c|c|c|c|}
\hline \multirow{2}{*}{ Year } & \multirow{2}{*}{$\begin{array}{c}\text { Number of } \\
\text { companies }\end{array}$} & \multicolumn{2}{|c|}{ Distress Zone } & \multicolumn{2}{c|}{ Safe Zone } & \multicolumn{2}{c|}{$\begin{array}{c}\text { Model is not } \\
\text { applied }\end{array}$} \\
\cline { 3 - 8 } & & Firms & $\%$ & Firms & $\%$ & Firms & $\%$ \\
\hline k-1 & 433 & 324 & 74.8 & 13 & 3 & 96 & 22.2 \\
\hline k-2 & 416 & 330 & 79.3 & 26 & 6.3 & 60 & 14.4 \\
\hline k-3 & 302 & 253 & 83.8 & 0 & 0 & 49 & 16.2 \\
\hline k-4 & 156 & 129 & 82.7 & 0 & 0 & 27 & 17.3 \\
\hline k-5 & 65 & 34 & 52.3 & 17 & 26.2 & 14 & 21.5 \\
\hline Ratio indices that are impossible to calculate are equalled to $0:$ & & & \\
\hline k-1 & 433 & 261 & 60.3 & 170 & 39.3 & 2 & 0.5 \\
\hline k-2 & 416 & 173 & 41.6 & 243 & 58.4 & - & \\
\hline k-3 & 302 & 143 & 47.4 & 159 & 52.6 & - & - \\
\hline k-4 & 156 & 53 & 34.0 & 103 & 66.0 & - & - \\
\hline k-5 & 65 & 15 & 23.1 & 50 & 76.9 & - & - \\
\hline
\end{tabular}

Source: created by the authors

To generalize, the analysis of each of the above mentioned bankruptcy prediction models in Lithuanian companies revealed that the logistic regression Chesser model (more precisely, a variation of the model when ratio indices that are impossible to calculate (due to impossible division from 0) are equalled to 0) and the Zavgren model show the highest bankruptcy probability and are the most accurate ones to determine bankruptcy prediction (Table 9). The accuracy of the linear discriminant Springate model is also very high.

Table 9. The accuracy of the investigated bankruptcy prediction models (\%)

\begin{tabular}{|c|c|c|c|c|c|c|c|c|c|}
\hline Year & $\operatorname{Altman}^{1}$ & $\operatorname{Altman}^{2}$ & Altman $^{3}$ & Springate & Taffler & $\begin{array}{c}\text { Taffler \& } \\
\text { Tisshaw }\end{array}$ & Chesser & Chesser $(c)^{4}$ & Zavgren \\
\hline $\mathrm{k}-1$ & 76.7 & 76.7 & 55.9 & 88.7 & 35.8 & 74.4 & 72.7 & 91.5 & 74.8 \\
\hline $\mathrm{k}-2$ & 51.4 & 56.5 & 29.6 & 67.1 & 28.1 & 61.3 & 67.5 & 78.1 & 79.3 \\
\hline $\mathrm{k}-3$ & 43.0 & 46.7 & 20.9 & 55.0 & 23.8 & 54.6 & 55.6 & 65.2 & 83.8 \\
\hline $\mathrm{k}-4$ & 42.3 & 43.6 & 23.7 & 53.8 & 23.7 & 51.3 & 50.6 & 58.3 & 82.7 \\
\hline $\mathrm{k}-5$ & 29.2 & 35.4 & 15.4 & 44.6 & 20.0 & 38.5 & 46.2 & 56.9 & 52.3 \\
\hline
\end{tabular}

${ }^{I} Z$ '-Score model for companies whose shares are not quoted in stock-exchange markets

${ }^{2} \mathrm{Z}$ "-Score model for the service companies

${ }^{3}$ Z"-Score model for emerging countries

${ }^{4}$ Adapted Chesser model - Chesser model in ratio indices that are impossible to calculate (due to impossible division from 0 ) are equaled to 0 .

Source: created by the authors

The examination of the construction sector reveals that the adapted Chesser bankruptcy prediction model has the accuracy of $91.5 \%$ one year before the bankruptcy initiation (i.e. the highest of all investigated models); the Springate model shows the accuracy of $88.7 \%$; the Zavgren model shows the accuracy of $74.8 \%$. Two years before the bankruptcy initiation, the accuracy of the Chesser model declines to $78.1 \%$ and that of the Springate model to $67.1 \%$ respectively. The Zavgren model appears to be most accurate when the period of two years before filing for bankruptcy is considered - it reaches the accuracy of $79.3 \%$. It has the highest accuracy 3-4 years before filing for bankruptcy as well. The adapted Chesser model is most accurate five years before 
filing for bankruptcy. The drawback of the Zavgren model is that it cannot be applied in 14-22\% of companies as ratio indices used in the model cannot be calculated. This model cannot be adapted because then the accuracy of the model diminishes significantly.

One cannot claim, however, that other models are improper to predict bankruptcy of companies. Nevertheless, having in mind that the research embraces 433 companies, the adapted Chesser, Zavgren and Springate models show the highest accuracy. Whereas the results of the original Chesser model are not high: the accuracy of the model is lower than those of Altman Z'Score, Z"-Score for the service companies, Zavgren models.

\section{Discussion}

The analysis of scientific literature revealed that scholars have different opinions concerning created bankruptcy prediction models. Some authors claim that bankruptcy prediction models might be applied in practice on condition that they are adapted. Others state that it is pointless to apply these models because the economic environment and periods of time differ, whereas the abundance of the factors that must be considered make it inexpedient to construct analogical indicators or rely on experimental methods. Empirical research studies provide conflicting results as well. Having performed the analysis of the empirical research, which has been carried so far, it was determined that during the research companies of different branches were tested. Also, conclusions about the applicability of bankruptcy prediction models in Lithuanian companies were drawn only after testing a small sample of companies. It was only Jurevičienè and Bercevič's (2013) research that was oriented to the transport sector; however, only 10 companies were investigated.

The majority of empirical research studies that were carried out by applying bankruptcy prediction models in Lithuanian companies showed that the Altman's models are suitable for the bankruptcy prediction in Lithuanian companies. A very wide range of the application of these models is proposed by Mackevičius and Rakštelienè (2005): the scholars suggest applying all three Altman's models to predict bankruptcy in Lithuanian companies. Empirical research authors also approve of the application of the Springate, Taffler \& Tisshaw models. Garskaite (2008) found the Taffler \& Tisshaw model to be the most accurate one of linear discriminant analytical models; while Mackevicius and Silvanaviciute (2006) compare linear discriminant analytical models with logistic regression models and note that 1) the most accurate bankruptcy probability was obtained by linear discriminant analytical models: Altman, Springate, Taffler \& Tisshaw; 2) the results of logistic regression models - Zavgren and Chesser - were contradictory, they often did not reflect real financial state of the companies.

To achieve the aim of the research, i.e., to evaluate the applicability of bankruptcy prediction models in Lithuanian companies in the construction sector, classical statistical bankruptcy prediction models were chosen: linear discriminant analytical models (Altman, Springate, Taffler) and logistic regression models (Chesser, Zavgren). In order to evaluate the accuracy of bankruptcy prediction models, empirical calculation of 433 companies in the construction sector whose bankruptcy processes were initiated in 2009-2013 was carried out.

Having applied linear discriminant analytical models in Lithuanian companies in the construction sector, the following was found out:

1) The Springate bankruptcy prediction model is the most accurate one. The Springate model reached $88 \%$ accuracy. In Lithuanian companies such accuracy is obtained only if the model is applied one year before bankruptcy initiation. However, the drawback of this model is that the more time there is left to bankruptcy, the less accurate the model becomes in companies in the construction sector: when data of a two-year period before the bankruptcy initiation is being examined, the accuracy of the model is $67.1 \%$; the accuracy of the model decreases even more when the data is tested three years before the bankruptcy initiation.

2) Not all Altman's models may be applicable for the bankruptcy prediction in Lithuanian companies in the construction sector. Neither of the tested models reaches the accuracy of the Altman's model (the possibility to indicate the probability of a company's bankruptcy is up to $95 \%$ 
one year before the bankruptcy initiation and $72 \%$ two years before the bankruptcy initiation). In case of Lithuanian construction companies, the accuracy of two Altman's models ( $Z$ '-Score model for companies whose shares are not quoted in stock-exchange markets and Z"-Score model for the service companies) is lower by 18 percentage points when bankruptcy is being predicted one year before bankruptcy initiation. The accuracy of the Z"-Score model for emerging countries is even lower: it is lower by 39 percentage points when bankruptcy is being predicted one year before bankruptcy initiation. Therefore, this model may be regarded as one of the least accurate models for the bankruptcy prediction in Lithuanian companies in the construction sector.

3) Garskaite's (2008) research results, according to which the Taffler \& Tisshaw model was claimed to be the most accurate one, did not prove out completely. The accuracy of the Taffle \& Tisshaw model in Lithuanian companies in the construction sector is lower by 14 points (when predicting company bankruptcy one year before the bankruptcy initiation) compared to the accuracy of the Springate model. The accuracy of the Taffle \& Tisshaw model one year before the bankruptcy initiation is $97 \%$, and the model accuracy is lower by 23 percentage points in case of Lithuanian construction sector companies.

4) The research proved that the Taffler model is the least accurate bankruptcy prediction model.

By applying logistic regression models for bankruptcy prediction in Lithuanian companies in the construction sector, the following was found out:

1) Earlier research studies showed that the results of logistic regression models - Zavgren and Chesser - were contradictory, they often varied from real financial state of the companies; the accuracy of these models is lower than that of linear discriminant analytical models. In Lithuanian companies of the construction sector, the accuracy of the Zavgren and Chesser models ( $Z$ '-Score model for companies whose shares are not quoted in stock-exchange markets and Z"-Score model for the service companies) corresponds to the accuracy of the Altman's models.

2) The accuracy of the Chesser bankruptcy prediction model is $78 \%$ one year before bankruptcy initiation; the research of the situation in Lithuania shows similar results.

3 ) The accuracy of the Zavgren model is $75-79 \%$ one year before bankruptcy initiation. The attention should be brought to a rather paradoxical situation: in the construction sector, the model is more accurate when the data of 2-4 years before the bankruptcy initiation is considered in comparison with the examination of the data one year before the bankruptcy initiation. What is more, the Zavgren model distinguishes itself from other models by being the most accurate one for the bankruptcy prediction 2-4 years before bankruptcy initiation.

Investigated models use financial ratios to evaluate bankruptcy. There might be cases when a model cannot be applied because the denominator of the ratio fraction is equal to 0 . By applying bankruptcy prediction models in Lithuanian companies in the construction sector the following was found out:

1) Such cases are very rare in linear discriminant analytical models and have no impact on the accuracy of the models.

2) The Chesser model could not be applied for a huge number of companies, i.e. $21 \%$ of companies (a year before filing for bankruptcy), 14\% of companies (three, five years before filing for bankruptcy). The model accuracy increases significantly if ratio indices that are impossible to calculate are equalled to zero. It was discovered that in such case the model could not be applied only up to $1 \%$ of companies. In addition to this, when the Chesser model is adjusted in such a way, it becomes the most accurate bankruptcy prediction model in Lithuanian companies in the construction sector.

3) It was revealed that in such case, Zavgren model could be applied to practically all companies, but the accuracy of the model decreased significantly. Thus, the adjustment of the Zavgren model would be inappropriate. 


\section{References}

Altman, E.I., Danovi, A. \& Falini, A. (2013). Z-Score Models' Application to Italian Companies Subject to Extraordinary Administration. Journal of Applied Finance, 23 (1), 128-137.

Bivainis, J. \& Garškaite, K. (2000). Evaluation of Enterprises’ Bankruptcy Threat. Economics, 51, 7-19.

Boritz, J. E., Kennedy, D. B., Sun, J. Y. (2007). Predicting Business Failures in Canada. Accounting Perspectives, Vol.6(2), 141-165.

Budrikienè, R. \& Paliulyte, I. (2012). Applicability of Bankruptcy Prediction Models for Companies of Different Solvency and Profitability. Economics and Management: Current Issues and Perspectives, 2(26), 90-103.

Garškaite, K. (2008). Application of Models for Forecasting of Enterprise Bankruptcy. Business: Theory and Practice, 9(4), 281-294.

Grigaliūnienè, Ž. \& Cibulskienè, D. (2004). Application of Bankruptcy Diagnostics Methodology under Lithuanian Economic Conditions. Economics and Management: Current Issues and Perspectives, 4, $105-114$

Harris, P. (2010). Accounting and Finance for the International Hospitality Industry. Taylor \& Francis.

Jurevičienè, D. \& Bercevič, E. (2013). The Evaluation of Bankruptcy Prediction Models for Lithuanian Companies. Trends Economics and Management, 7 (13), 43-55.

Kanapickienė, R., Rudžionienė, K. \& Griauslyte, R. (2008). Forecasting Company Bankruptcy: Lithuanian Case. Business Analysis, Accounting, Taxes and Auditing, 52-56.

Karalevičienè, J. \& Bužinskienè, R. (2012a). The Suitability Evaluation of Modern Bankruptcy Models for Enterprises Bankruptcy Diagnosis. Journal of Management, 1 (20), 45-54.

Karalevičienè, J. \& Bužinskienė, R. (2012b). The Transformation Structure and Development of Traditional and Modern Bankruptcy Model. Accounting, Audit, Analysis: Science in the Context of Innovation and Globalization, 212-227.

Kasilingam, R. \& Ramasundaram, G. (2012). Predicting Solvency of Non-Banking Financial Institutions in India Using Fulmer and Springate Model. Journal of Services Research, 12(1), 65-88.

Kiyak, D. \& Labanauskaite, D. (2012). Assessment of the Practical Application of Corporate Bankruptcy Prediction Models. Economics and Management, 17 (3), 895-905.

Mackevičius, J. (2010). Integrated Business Bankruptcy Forecasting Methodology. Current Issues of Business and Law, 5, 123-138.

Mackevičius, J. \& Rakštelienè, A. (2005). Employing Altman's Models to Predict Bankruptcy of Lithuanian Companies. Monetary Studies, 1, 24-42.

Mackevičius, J., \& Poškaitè, D. (1999). Imonių bankroto prognozavimo analizès metodikų tyrimas, remiantis finansinių ataskaitų duomenimis. Economics, 49, 541-63.

Mackevičius, J., \& Silvanavičiūtè, S. (2006). Evaluation of Suitability of Bankruptcy Prediction Models. Business: Theory and Practice, 7(4), 193-202.

Purvinis, O., Šukys, P. \& Virbickaitè, R. (2005). Research of the Possibility of Bankruptcy Diagnostics Applying Neural Network. Engineering Economics, 41(1), 16-22.

Shemetev A. (2012). Complex Financial Analysis and Bankruptcy Prognosis and also Financial Management-Marketing Manual for Self-Tuition Book. Saint-Petersburg, 750 p.

Statistics Lithuania. (2014). Bankruptcy processes completed. Retrieved September 4, 2014, from: www.osp.stat.gov.lt/en/ web/guest/imoniu-bankrotas-rodikliai.

Tvaronavičienè, M. (2001). Approaches to Enhancing of Efficiency of Enterprises’ Bankruptcy Process. Economics, 54, 135-143.

Zavgren, Ch. (1985). Assessing the Vulnerability to Failure of American Industrial Firms: a Logistic Analysis. Journal of Business Finance \& Accounting, 12(1), 19-45. 